1 研究課題名: 細菌毒素の宿主細胞内輸送経路の解明と新規治療法開発の試み

2 研究者氏名:藤永由佳子

技術員:株本 祐子（研究期間 H.15.4.1 H.17.12.31）

3 研究のねらい:

多くの細菌毒素は微量で宿主細胞の機能分子に特異的作用を及ぼし、結果的に宿主に致死など大きな影響を与 える。細菌毒素がこのような強力な作用を発揮できる理由の一つとして一般的に考えられているのは、多くの細菌 毒素が微量でも宿主の機能に影響を与えることができる酵素であるということである。もう一つ重要な細菌毒素の特 質として、作用する基質に効率よくターゲティングする機構すなわち巧妙な輸送機構をもつ場合が多いことが挙げら れる。その輸送機構は、もともと細胞が基本的·生理的にもっている膜輸送系やオルガネラの機能をうまく利用して いる場合が多いと考えられる。従って細菌毒素の輸送経路の研究は、毒素による病態発現機構の解明という意義 に加えて、従来知られていなかった宿主細胞の基本的で重要なしくみを明らかにできる可能性も秘めている。いず れにしてもこのような研究は外来病原因子の侵入に対する宿主の防御システムを理解し制御する上で重要である。

我々は腸管上皮細胞を場として毒素の輸送機構の研究を展開しているが、この細胞は多くの細菌毒素がその毒 性を発揮するための標的となり、あるいは宿主動物へ侵入する際の門戸となっている。本 project では、前者の例と して腸管上皮細胞に作用して細胞内 cAMP を上昇させるコレラ毒素、後者の例として腸管上皮細胞バリアを通過し てボツリスス食中毒を引き起こすボツリヌス神経毒素複合体の輸送経路の解明を目指す。

4 研究成果:

\title{
1）コレラ毒素の腸管上皮細胞内輸送経路の解明
}

コレラ毒素は、小腸上皮細胞の apical 側か ら取り込まれ、細胞質中の Gs タンパク質を ADP-リボシル化することにより cAMP の上昇 を引き起こし、下痢を起こすことはよく知られ ているが、腸管上皮細胞内でどのように輸送 されて Gs に到達するのかは不明であった。 我々は、コレラ毒素の sulfation によりゴルジ 体への移行と、glycosylation により小胞体へ の移行を検出することで、コレラ毒素の輸送 経路を明らかにすることに成功した(図 1)。毒 素はホ口毒素の状態で細胞膜から小胞体ま で輸送されること、そしてその輸送は $\mathrm{B}$ サブ ユニットが主体となり、 $\mathrm{B}$ サブュニットが脂質 ラフト中の GM1 に結合することで行われてい ることが明らかになった。一方、脂質ラフトに 存在していない糖脂質は毒素をゴルジ体や 小胞体まで輸送しない。

図 1 コレラ毒素の細胞内輸送経路の解析

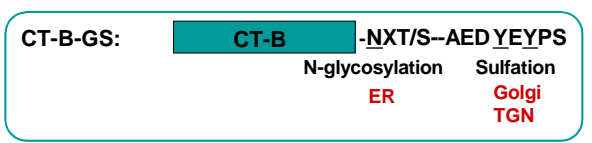

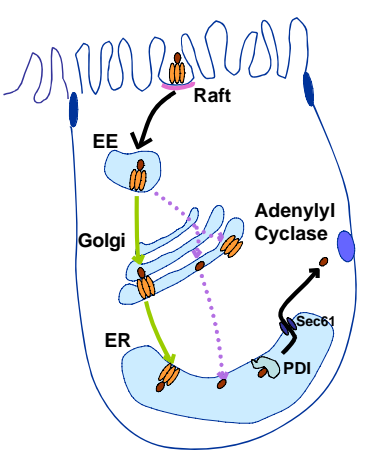

1. B サブュニットはゴルジ体を経て小 胞体へ輸送される。

2. コレラ毒素はホロ毒素として小胞 体まで輸送される。

この輸送の sorting factor はGM1 であり、raftへの結合が重要である。 Y.Fujinaga, et al.
Mol. Biol.cell. 14, 4783-4793 (2003)

コレラ毒素以外の毒素やウイルスでその病原性を発揮するために小胞体へ輸送されるものがいくつかある。最近 その多くがガングリオシドに結合して小胞体へ輸送されることがわかってきた。したがって本経路は多くの病原因子 が細胞質に到達しその病原性を発揮するために利用する共通の経路であることが明らかになってきた。(本研究の 一部をさきがけ事業で行った。)

\section{2） ボツリヌス毒素複合体の腸管上皮バリア通過機構の解析}

ボツリヌス食中毒は、ボツリヌス神経毒素(7S 毒素、約 $150 \mathrm{kDa}$ のタンパク質、A 型へG型)により引き起される （図 2)。本神経毒素はメタロエンドペプチダーゼであり、末梢神経細胞に取り込まれた場合シナプス小胞とシナプス 前膜の fusion に関わる SNARE を特異的に切断することにより神経伝達物質の放出を抑制する。個体(ヒトあるいは 動物)においては、末梢運動神経の弛緩性麻痺を引き起こし呼吸困難による致死をもたらす。本食中毒発症には、 神経毒素が消化管から吸収され、血中に移行し末梢運動神経に到達することが必要である。このような巨大分子で ある神経毒素が体内に侵入する際の最初の重要な関門は消化管上皮細胞のバリア機能である。一方、本毒素は 
常に無毒成分との複合体(12S 毒素および 16S 毒 素など)として C. botulinum が産生する。12S 毒素 は 7S 毒素に無毒性で赤血球凝集活性のないタン パク質であるNTNH が結合したものであり、16S 毒 素は 12S 毒素に無毒性で赤血球凝集活性をもつ Hemagglutinin（HA）が結合したものである。19S 毒素は16S 毒素の二量体である。それらの経口毒 性は 7S 毒素 $<12 S$ 毒素 $<16 S$ 毒素と、大きい分 子量の複合体毒素の方が著しく強いことが知られ ているが、その理由については、無毒成分に神経 毒素を消化液から保護する作用があること以外は 不明であった。

我々は $16 \mathrm{~S}$ 毒素がHAを介して小腸上皮細胞に 特異的に結合することを以前に見出している。こ の結合様式の解析をさらに進め、HA の 4 つのサ ブュニットの中で HA1 と HA3b に腸管上皮細胞へ
図2ボツリヌス毒素複合体とボツリヌス食中毒
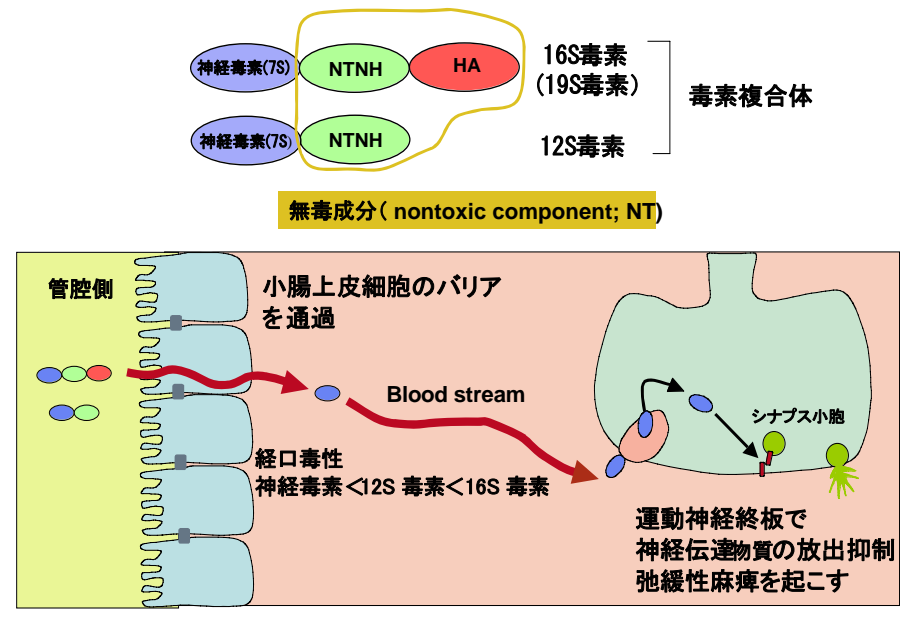

の結合活性があること、およびそれぞれが異なる糖鎖を認識することを本研究期間に明らかにした。

次に我々は HAなどの無毒成分が神経毒素の腸管上皮細胞バリア通過を促進するのか、またどのような相互作 用をするのかを分子レベルで検討する目的で、ヒト腸管上皮細胞株 Caco-2 およびT84を用いた in vitro腸管上皮細 胞バリアモデルで解析を行った。その結果、B 型 16S毒素 50nM を apical から添加した場合は、細胞間のバリアであ る tight junction には変化が見られなかったが、 basolateral の培地中には神経毒素および無毒成分（HA1 と HA3b） が移行していることが western blot によって確認された(図 3)。さらに蛍光ラベルした無毒成分を apical から添加し た場合の局在を confocal 顕微鏡で観察した結果、無毒成分は小胞状で取り込まれた後、おそらく transcytosisによ って basolateral 側へ移行していることが観察された。以上の結果より、16S 毒素は HA を介して腸管上皮細胞の apical 側へ結合した後、transcytosisにより神経毒素を basolateral 側へ移行させることが示唆された(図 4)。
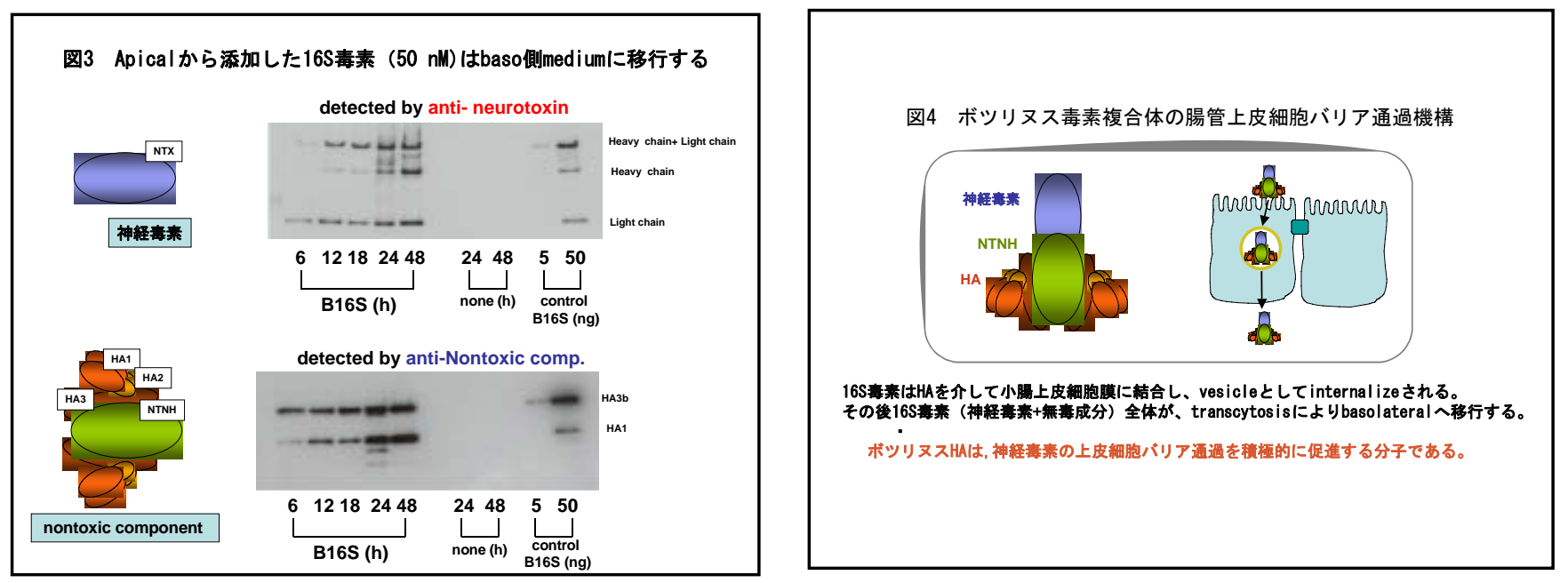

\section{5 自己評価:}

コレラ毒素の輸送系の研究は継続的な研究であったため、当初の目標をほぼ達成できた。ボツリスス神経毒素の 研究は、毒素の精製、抗体作製、in vitro、in vivoの assay 系の確立を行い、毒素の移行に関しての現象を発見する ことは期間内に行うことができたが、そのメカニズムについての研究は期間内の成果として公表するところまでには 至らなかった。引き続き研究を行い、現象とそのメカニズムの解明を含めた形で、期間終了後一年以内に論文発表 などにより公表していきたい。

\section{6 研究総括の見解:}

本研究は、腸管上皮細胞を毒性発揮の標的としているコレラ毒素と、腸管上皮細胞を宿主への侵入門戸として いるボッリヌス毒素について、毒素の細胞内輸送経路を明らかにすることを目的として行った。その結果、コレラ毒 素はホロ毒素の状態で細胞膜から小胞体まで輸送されること、その輸送は B サブユニットが脂質ラフト中の GM 1 ガ 
ングリオシドに結合することで行われていることを明らかにした。一方ボッリヌス毒素については、毒素の精製、抗体 作製。in vitro, in vivoの assay 系の確立を行ったものの、毒素の移行に関しての現象の解析を行うには至らなかっ た。今後の研究に期待したい。

\section{7 主な論文等:}

論文

1. Fujinaga Y, Wolf AA, Rodighiero C, Wheeler H, Tsai B, Allen L, Jobling M, Rapoport T, Holmes RK, Lencer WI. Gangliosides that associate with lipid rafts mediate transport of cholera and related toxins from the plasma membrane to ER. Mol. Biol. Cell. 14(12): 4783-93 (2003).

2. Fujinaga $Y$, Inoue K, Watarai S, Sakaguchi $Y$, Arimitsu H, Lee J, Jin Y, Matsumura T, Kabumoto Y, Watanabe T, Ohyama T, Nishikawa A, Oguma K. Molecular characterization of binding subcomponents of Clostridium botulinum type $C$ progenitor toxin for intestinal epithelial cells and erythrocytes. Microbiology 150:1529-1538 (2004).

3. Nishikawa A, Uotsu N, Miura Y, Fujinaga Y, Nakada H, Ohyama T, Sakano Y, Oguma K. The receptor and transporter for internalization of Clostridium botulinum Type C Progenitor Toxin. Biochem. Biophys. Res. Commun.. 319(2): 327-33 (2004).

4. Fujinaga Y.: Interactions of botulinum progenitor toxin and cholera toxin wit host intestinal epithelial cells. J. Toxicol.Toxin Rev. (in press)

5. Fujinaga Y.: Transport of bacterial toxins into target cells: pathway followed by cholera toxin and botulinum progenitor toxin. J.Biochem.. (in press)

\section{受賞}

日本細菌学会平成 15 年度黒屋奨学賞

\section{招待講演}

第 29 回阿蘇シンポジウム (2005 年 7 月) 